\title{
The Effects of Blended Learning on Foreign Language Learners' Oral English Competence
}

\author{
Xuan Teng \\ Foreign Studies College, Hunan Normal University, Changsha, Hunan Province, 410081, China \\ Ying Zeng \\ Foreign Studies College, Hunan Normal University, Changsha, Hunan Province, 410081, China
}

\begin{abstract}
Attainment of oral competence is an important goal for English teaching and learning in middle schools in China. However, the level of Chinese middle school students' oral proficiency is in general less than satisfactory. To find a possible solution to this issue, this study empirically investigated the effect of blended learning on the development of foreign language learners' oral English competence. Following the blended model and the four-step pedagogical method for teaching speaking (Wang, 2014), the experimental class, consisting of 46 junior middle school students, participated in this study and took a pretest, an immediate posttest, a delayed post-test, and an interview. Their test scores were compared with the control class which involved 45 junior middle school students receiving the traditional teaching method and following the same procedure. The results showed that the blended learning method had remarkable effect on the improvement of oral accuracy and fluency, but not complexity. In addition, the blended environment facilitates the encoding process of the input and the actualization of the transition from object- and other-regulation to self-regulation.
\end{abstract}

Index Terms—blended learning, oral competence, Chinese EFL learners

\section{INTRODUCTION}

The development of oral English competence is an important learning objective for junior middle school students in China. The National English Curriculum Standards for Common Senior High School issued by the Chinese Ministry of Education in 2017 (henceforth the new NEC) states that students' ability to express ideas smoothly and communicate with others effectively is the teaching and learning target for speaking classes. Particularly, students are expected to provide information and express opinions on simple topics, participate in discussions and conduct situational dialogues, communicate and cooperate with others to complete tasks, make appropriate self-correction in oral expressions, and make sound, intonation, and tone appropriately in oral activities. On the other hand, junior middle school students' oral competence is in general less than satisfactory, largely due to the lack of sufficient training in oral communication. There is usually a very small amount of class hours spent on listening and speaking teaching, and the class size is more often than not very large, making it difficult for teachers to set effective group activities for students to practice speaking (Bahanshal, 2013). Even in listening and speaking classes, students are often engaged in controlled, accuracybased activities that aim for consolidation of grammar knowledge. There is little, if any, real communication between the students, which makes the activities dull and boring, and is less likely to contribute to their growth in the use of the foreign language autonomously and creatively.

As a possible solution to the problems in teaching speaking, blended learning enables students to practice speaking and improve oral competence in a more interactive and autonomous way. Blended learning can be loosely defined as a teaching method that combines traditional classroom face-to-face learning and online learning (Garrison \& Kanuka, 2004), and online learning is often delivered through the use of a web-based platform. Studies (e.g., Osgerby, 2013) found that blended learning, especially the platform, is advantageous for sharing learning materials, creating an active online learner community, and promoting teacher-student and student-student interaction. In addition, students in a blended learning environment are able to learn at their own pace and keep themselves on task, thereby increasing learner autonomy (Ayesha, 2020). In a nutshell, integrating elements of technology into foreign language classrooms can enhance students' learning experience by making learning more interactive, autonomous, and perhaps more important, enjoyable for all involved.

Despite the aforementioned benefits, in China where English is the predominant foreign language, over the past decade, very few studies has been conducted in relation to the effect of blended learning on foreign language development, and only a handful of studies has examined its role in promoting oral English competence. Particularly, Gong (2008) designed a spoken English teaching framework based on blended learning and found that its application could effectively improve college students' spoken proficiency and mastery of various learning methods. Gao (2019) used the Homework Box as an online learning platform to construct a blended learning model and found that the model could improve primary school students' listening and speaking ability, learning interest and learning initiative. As these 
studies suggested, blended learning in general plays a facilitative role in cultivating foreign language learners' oral English competence and language learning skills.

Until now, there remains a paucity of empirical research on the impact of blended learning on the growth of middle school students' oral English competence. Nevertheless, from the year of 2015, the entrance examination for senior middle schools in China has gradually incorporated the oral test of human-machine dialogue as part of the test, and the results are included in the total score of the entrance examination. Since the examination places a high demand on students' oral English competence, including answering questions in different contexts, telling stories according to pictures, using accurate pronunciation and intonation (Zou, 2016), it is of practical value to investigate the extent to which blended learning can contribute to development of junior middle school students' oral competence to better meet the requirements set by the entrance examination.

\section{LITERATURE REVIEW}

\section{A. The Definition and Models of Blended Learning}

It is generally agreed that blended leaning is the learning method combining offline face-to-face learning with online learning, and emphasizes the use of computer-based technologies (Graham, 2006). In China, the renowned educational technology theorist and practitioner, professor He Kekang, echoed this definition by interpreting blended learning as the combination of "the advantages of traditional learning methods with those of E-learning (e.g. digital learning or network learning)" (He Kekang, 2004). Blended learning offers the richness and diversity of online resources, and compensates for the disadvantages of online learning. During the COIVD-19 pandemic, the need for a paradigm shift in the education system to create and deliver technology dependent learning environments to a large extent accelerated the growth of blended learning. Additionally, according to the distribution of face-to-face and online instruction, blended learning can be categorized into various models. For example, Barnum and Paarmann (2002) proposed a four-step model of blended learning: learning on the web before class, face-to-face learning and construction, learning product, and collaborative extended learning. Horn and Staker (2011), based on the implementation of blended learning in 80 schools in the United States, proposed six categories of blended learning models: face to face driver model, rotation model, flexible model, online club model, self-blended model, and online driver model. To sum up, blended learning is not a simple mixture of different teaching forms, but a synthesis of teaching ideas, models and organizational methods, with a view to innovation and creation.

In the present study, blended learning is defined as the integration of traditional face-to-face instruction with network-based instruction, and it is the combination of teaching methods, media, models, content, resources, environment, and other teaching elements to achieve the optimum teaching effect. Furthermore, based on the characteristics of blended learning and foreign language teaching, a model for teaching oral English in a blended environment is constructed and implemented to better suit the context of the present study. In this model, students play the central role through online, offline, and self-paced learning, and teachers are the guide and resource provider who make use of technology to optimize students' learning and teachers' teaching.

\section{B. Components and Measurement of Oral Competence}

The complexity, accuracy, and fluency (also known as CAF) triad has long been viewed as the major variables for measuring oral competence (e.g. Skehan, 1998; Norris \& Ortega, 2003, Ellis, 2003, 2008; Ellis \& Barkhuizen, 2005). The new NEC supports the relevance of the triad by stipulating that oral English proficiency includes the ability to use the correct grammar, vocabulary and pronunciation to express ideas fluently and appropriately in different communicative situations. Among the three variables in the triad, complexity refers to "size, elaborateness, richness, and diversity of the learner's linguistic L2 system (Housen \& Kuiken, 2009, p. 5)" and is usually measured by syntactic complexity. Accuracy indicates the degree of deviancy from a particular norm (Wolfe-Quintero et al., 1998). Deviations from the norm are in general characterized as errors, and therefore accuracy is usually measured by error-free clauses (Foster \& Skehan, 1996). Fluency denotes the ease, eloquence, and smooth of speech (Chambers, 1997; Freed, 2000, Koponent \& Riggenbach, 2000, Lennon, 1990) and is measured by three main factors: speed, breakdown, and repair (Skehan, 2003). It should be noted that fluency and accuracy are the most important criteria for assessing learners' oral competence (Lenon, 1990), and they are often at opposition. In other word, those who speak accurately may not speak fluently, and vice versa (Ong \& Zhang, 2010). Additionally, learners can not improve their oral proficiency simply by increasing their oral fluency if the accuracy of their oral production remains the same. This competitive relationship within CAF, as Skehan (2009) noted, is because of one's limited mental resources, specifically attentional capacity and working memory.

\section{Oral English Teaching in Junior Middle Schools in China}

Being competent in speaking, that is, speaking accurately and fluently, is vital to English learners' overall foreign language ability development (Goh, 2007), academic achievement, and professional success (Saunders \& O'Brien, 2006). Nevertheless, in the context of Chinese education, oral English teaching and learning has not received adequate attention from teachers and students. This is due to the fact that most English class sizes in Chinese middle schools are large, and the class is more often than not dominant by teacher talk, leaving the students very few chances to practice 
speaking. This problem is compounded by the fact that many middle school teachers, especially those in rural areas, are deficient in oral accuracy and fluency, and thereby are incapable of providing students the correct models to imitate. The students, on the other hand, due to the pressure of obtaining good grades in exams, focus more on the study of grammar rules and vocabulary than the use of English for communication. Overall, the current situation of oral English teaching in junior middle schools in China calls for the adoption of new teaching methods, and how to improve students' oral English competence is of great concern to teachers and researchers.

Recently, a number of studies in China have been conducted in relation to the possible solutions to the problems existing in oral English teaching. For the lack of adequate models, some studies show the promise of incorporating technology for increasing exposure to input. For example, Liu's (2020) research on the effect of the "Ekwing" platform hierarchical assignments on junior middle school students' oral English proficiency demonstrated that the platform was useful for students in correcting oral problems and constructing new knowledge through independent practice. Similarly, Zhang's (2020) study on the utilization of the "English Fluent Speaking" mobile application for oral English teaching in a junior middle school showed that the application could demonstrate voice and intonation, correct students' pronunciation, and promote oral communication ability. Another strand of research concerns the benefit of the increase in oral practice frequencies. Particularly, Wang's (2021) action research on the effect of multidimensional interactive teaching on oral English development suggested that the increase in time and space (in and after class) of oral production resulted in the significant improvement in the fluency, coherence, pronunciation, intonation, content and logic of junior middle school students' oral expressions. Additionally, Ma's (2018) study showed that the addition of oral presentation in classroom teaching led to junior middle school students' growth in vocabulary, pronunciation, and interactive communication. Overall, it can be concluded that the provision of online technology and opportunities for practice, which blended learning is advantageous for, is beneficial for promoting foreign language learners' oral competence.

\section{Studies on the Effect of Blended Learning}

The past decade witnesses the burgeoning of the application of blended learning to the context of K-12th grade (Hesse, 2017) and higher education (Evans et al., 2019; Lopez-Perez et al. 2011), and most of these studies focuses on the development of students' academic achievement (Ceylan \& Kesici, 2017; Senturk, 2021) and critical thinking skills (Borglum, 2016; Hasanah \& Malik, 2020). In the field of foreign language teaching and learning, many studies were conducted in relation to the effect of the blended environment on the improvement of reading (Ghazizadeh \& Fatemipour, 2017) and writing skills (Lam et al., 2017; Wahyuni, 2018). In the context of Chinese education, on the other hand, the majority of the researchers are concerned with the construction of theoretical framework and organizational model for the design of a blended learning courses (Tong, 2017; Xu, 2015), whereas the empirical investigation into the effectiveness of blended learning is in general lacking.

Thus far, studies conducted by Roso-Bas et al. (2020) and Ehsanifard et al. (2018) seem to be the only empirical investigation into the effect of blended learning on the promotion of oral competence. Specifically, both studies suggested the positive role that the blended environment had played in enhancing English learners' oral proficiency. Nevertheless, both studies were conducted with college students and used an overall score as the indicator of their oral competence. It was therefore unclear the extent to which blended learning contributes to the development of the complexity, accuracy, and fluency of middle school students' oral performance, and this is the topic that this study seeks to address.

\section{E. Theoretical Foundation}

\section{Object-, Other- and Self-Regulation}

"Regulation" is an important concept in the sociocultural theory (SCT) proposed by Russian psychologist Vygotsky. According to Vygotsky (1978), "regulation" is the process whereby humans gain better control of their biological and behavioral activities through cognition and interaction mediated by human-created tools and artifacts such as language (Frawley, 1997). Altogether there are three types of regulation: object, other, and self-regulation. For object-regulation and other-regulation, the sources of mediation are from artifacts in the environment, and verbal (Wertsch, 1979) and non-verbal (Foley, 1991) assistance of more capable peers, parents, or teachers, respectively. Self-regulation, on the other hand, is characterized by autonomous functioning, that is, an internally self-generated cognitive plan (Mitchell \& Myles, 1998). It is generally accepted that self-regulation comes after or because of regulation by objects and others (Anton, 1999). Development, in this sense, occurs when one gains greater voluntary control over his capacity to think and act "either by becoming more proficient in the use of meditational resources, or through a lessening of reliance on external meditational means" (Thorne \& Tasker, 2011, p.490).

\section{Dual-Coding}

The dual coding theory (DCT), proposed by the Canadian psychologist Allan Paivio in the 1970s, is based on the premise that the human cognitive system consists of two independent, and yet interconnected systems: verbal and nonverbal. The verbal system receives linguistic data and processes verbal information such as language, and the nonverbal system specializes in interpreting nonverbal stimuli such as mental imagery and emotional responses. Through connection to sensory input and response output systems as well as to each other, these two systems function 
independently and cooperatively in mediating verbal and nonverbal behavior. On this basis, Paivio (1991) put forward the idea that a combination of words and images is more effective than words alone in increasing information retrieval. This claimed benefit of dual-coding was later confirmed by studies (i.e., Paivio, 1991; Sadoski \& Paivio, 1994) comparing the effect of text plus picture versus text-only presentation and suggesting the advantage of the combination in facilitating learners' organization, processing, and retention of incoming information.

\section{METHODOLOGY}

\section{A. Questions}

As mentioned before, for the time being there are few studies focusing on the effect of blended learning on the development of oral English competence, particularly in the context of junior middle schools in China. This study therefore attempts to fill in the gap by seeking answers to the following questions:

1. What are the effects of blended learning on junior middle school students' development of oral competence in terms of complexity?

2. What are the effects of blended learning on junior middle school students' development of oral competence in terms of accuracy?

3. What are the effects of blended learning on junior middle school students' development of oral competence in terms of fluency?

\section{B. Participants}

This study was conducted in a junior middle school in the city of Changsha, Hunan Province. There are 46 students in the experimental class (EC), and 45 in the controlled class (CC). These two classes are parallel and intact classes, and are taught by the same English teacher. The participants have weekly oral English teaching hours and are at low intermediate level of oral English proficiency. Prior to the study, a monthly English achievement test was administered to the participants, and the scores, analyzed by the independent sample T test, suggested that there was no difference between these two classes in terms of overall English proficiency $(t=-0.774, p=0.441)$.

\section{Instruments}

Both quantitative and qualitative measures were used for data collection. Findings from quantitative and qualitative data were also triangulated to provide a detailed picture of the effect of blended learning on the development of oral English competence.

\section{Oral Tests}

Three oral English tests, namely a pretest, an immediate post-test, and a delayed post-test, are designed for both EC and $\mathrm{CC}$ to assess the changes in the participants' oral competence. The test items in these three tests are adapted from the human-machine oral English dialogue test for high school entrance of Changsha and contain three parts: questions and answers, guided oral presentation, and impromptu oral presentation. The three tests are comparable in difficulty and test administration conditions.

\section{Interview}

Semi-structured interviews were conducted with students in EC to obtain further, in-depth information about the effect of blended learning on students' oral competence. The interview questions elicit the participants' experience of using blend learning for oral practice, and their opinions about and suggestions for the application of blended learning.

\section{Procedure}

The experiment was carried out in September 2020, and lasted for 12 weeks until December 2020. Before the experiment, the participants in both EC and CC took the pretest. During the experiment, the traditional teaching method was used in CC, while the blended learning method was employed in EC. For the traditional teaching method, following Wang's (2014) four-step pedagogical method for teaching speaking to Chinese learners of English, the teaching process consists of four steps: pre-speaking, while-speaking, post-speaking, and extension practice. In the step of pre-speaking, the participants were engaged in pre-task planning, obtaining pre-speaking support, and receiving authentic input. In the while-speaking step, the participants developed their oral fluency through the completion of the speaking tasks, the use of fluency techniques, and the formation of automaticity. In the post-speaking step, the participants increased their oral accuracy by means of language-focused activities, self-repairs, and corrective feedback from the teacher and classmates. Finally, in the step of extension practice, the participants were involved in task repetition to increase both fluency and accuracy.

The teaching procedure for EC basically followed the above-mentioned four steps used in CC, with the integration of online technology. For Blended learning method, in the pre-speaking step, the teacher posted the learning resources, including video clips, audio files, discussion questions, PowerPoint slides, and assigned preview tasks on the online learning platform. The participants previewed the content of the learning resources, completed the preview tasks individually, and submitted their oral responses to the tasks virtually. The teacher listened to their responses and gave feedback accordingly. Meanwhile, the participants were free to share their questions and comments on the preview 
tasks through online posts. In the step of while-speaking, similar to $\mathrm{CC}$, the participants were guided to develop their oral fluency on the basis of speaking tasks, fluency technique training, and automaticity formation by the teacher through pair work or group work during face-to-face classroom interaction. In the post-speaking step, the participants were asked to submit their oral responses to the online platform, listened to the responses, and noted down the errors they had found in their online posts. They also received feedback from their peers and the teacher through online posts about the erroneous uses of grammar, vocabulary, and sentence patterns in their oral production. For extension practice, the teacher deployed the task repetition task as the homework assignment for students, and used the scores and autogenerated feedback from the mobile application for students to improve the accuracy and fluency of their speaking.

After the implementation of the four-step pedagogical method for 12 weeks, the participants in both EC and CC were asked to take the immediate post-test without notification in advance, and two weeks later, they completed the delayed post-test. Their oral responses to the test items were recorded and subsequently transcribed. Immediately after the delayed post-test, 10 participants from the EC were randomly selected for the interview. In order to gain deeper insight into the participants' opinions on the use of blended learning, they were allowed to answer the interview questions in Chinese if they were experiencing difficulty expressing themselves clearly in English. In total, 10 responses to the interview questions were recorded and then transcribed.

\section{E. Data Analysis}

Transcripts of the participants' responses to the three tests and the interviews were analyzed using the indexes for measuring CAF. Specifically, complexity is measured on the basis of the clause/T-unit ratio (Polio, 1997). A T-unit includes one main clause plus all subordinate clauses and non-clausal structures attached to or embedded in it (Foster et al., 2000), and the higher the clause/T-unit ratio is, the more complex the oral production is. Additionally, the error-free clause/clause ratio proposed by Foster and Skehan (1996) is adopted for measuring accuracy. Error-free clauses are counted by dividing the clauses that do not contain any error by the total number of clauses, and the higher the ratio is, the more accurate the oral production is. In this study, errors are the deviation from standard English, and according to Yuan and Ellis (2003), all errors relating to syntax, morphology, and lexical choice (including errors in lexical form or collocation) are investigated. For the measurement of both complexity and accuracy, a clause includes minimally of a finite or non-finite verb element and at least one another clause element (Foster et al., 2000). Finally, Rate B, the number of meaningful syllables per minute, is employed for measuring fluency. It calculates the number of syllables within each test item, but with all syllables, words, and phrases that are repeated, reformulated, or replaced excluded, divided by the number of seconds used to complete the test item, and multiplied by 60 . The higher the score of Rate B is, the more fluent the oral production is.

In this study, the independent variable is the use of blended learning for teaching oral English, the dependent variable is junior middle students' oral competence, specifically complexity, accuracy, and fluency. The quantitative data in this study includes the CAF measures for the three tests. The qualitative data is from the interview with 10 students in the EC.

\section{RESULTS AND DISCUSSION}

\section{A. Results}

\section{The Effect of Blended Learning on Oral Complexity}

As is presented in Table 1, the pretest results of EC and CC suggest that there is no obvious difference between EC and $\mathrm{CC}(\mathrm{p}=0.907>0.05)$ in terms of the clause/T-unit ratio. Therefore, the participants' oral complexity is at the same level, and both classes can be involved in the experiment.

TABLE 1

INDEPENDENT-SAMPLES T TEST OF COMPLEXITY PRETEST FOR EC AND CC

\begin{tabular}{|c|c|c|c|c|c|c|c|c|}
\hline \multirow{4}{*}{ Pretest } & & \multicolumn{2}{|c|}{$\begin{array}{l}\text { Levene's Test } \\
\text { for Equality } \\
\text { of Variances }\end{array}$} & \multicolumn{5}{|c|}{ T-test for Equality of Mean } \\
\hline & & $\mathrm{F}$ & Sig & $\mathrm{t}$ & $\mathrm{df}$ & Sig (2-tailed) & $\mathrm{M}$ & Std \\
\hline & $\begin{array}{c}\text { Equal } \\
\text { variances } \\
\text { assumed }\end{array}$ & \multirow{2}{*}{0.473} & \multirow{2}{*}{0.494} & -0.117 & 89 & 0.907 & -0.012 & 0.101 \\
\hline & $\begin{array}{c}\text { Equal } \\
\text { variances not } \\
\text { assumed }\end{array}$ & & & -0.117 & 88.738 & 0.907 & -0.012 & 0.101 \\
\hline
\end{tabular}

According to Table 2, the value of Sig. (2-tailed) is 0.946 , which is more than 0.05 . It can be concluded that the clause/T-unit ratio of the immediate post-test for EC and $\mathrm{CC}$ has no conspicuous difference, and the two classes are at the similar level of oral complexity after the experiment. 
TABLE 2

INDEPENDENT SAMPLES TEST OF COMPLEXITY IMMEDIATE POST-TEST FOR EC AND CC

\begin{tabular}{|c|c|c|c|c|c|c|c|c|}
\hline \multirow{4}{*}{$\begin{array}{r}\text { Immediate } \\
\text { post-test }\end{array}$} & & \multicolumn{2}{|c|}{$\begin{array}{c}\text { Levene's Test } \\
\text { for Equality } \\
\text { of Variances }\end{array}$} & \multicolumn{5}{|c|}{ T-test for Equality of Mean } \\
\hline & & $\mathrm{F}$ & Sig & $\mathrm{t}$ & df & $\begin{array}{c}\text { Sig } \\
\text { (2-tailed) }\end{array}$ & M & Std \\
\hline & $\begin{array}{c}\text { Equal } \\
\text { variances } \\
\text { assumed }\end{array}$ & \multirow{2}{*}{0.003} & \multirow{2}{*}{0.960} & -0.068 & 89 & 0.946 & -0.006 & 0.998 \\
\hline & $\begin{array}{c}\text { Equal } \\
\text { variances not } \\
\text { assumed }\end{array}$ & & & -0.068 & 88.766 & 0.946 & -0.006 & 0.998 \\
\hline
\end{tabular}

Table 3 indicates that in the delayed post-test, the value of Sig. (2-tailed) is 0.931, which is also higher than 0.05. Obviously, there are no big distinctions between the two classes in the delayed post-test, suggesting that EC and CC do not differ in their oral complexity after the two-week interval.

TABLE 3

INDEPENDENT SAMPLES TEST OF COMPLEXITY DELAYED POST-TEST FOR EC AND CC

\begin{tabular}{|c|c|c|c|c|c|c|c|c|}
\hline \multirow{4}{*}{$\begin{array}{l}\text { Delayed } \\
\text { post-test }\end{array}$} & & \multicolumn{2}{|c|}{$\begin{array}{l}\text { Levene's Test } \\
\text { for Equality } \\
\text { of Variances }\end{array}$} & \multicolumn{5}{|c|}{ T-test for Equality of Mean } \\
\hline & & $\mathrm{F}$ & Sig & $\mathrm{t}$ & df & $\begin{array}{c}\text { Sig } \\
\text { (2-tailed) }\end{array}$ & M & Std \\
\hline & $\begin{array}{c}\text { Equal } \\
\text { variances } \\
\text { assumed }\end{array}$ & \multirow{2}{*}{0.207} & \multirow{2}{*}{0.650} & -0.086 & 89 & 0.931 & -0.009 & 0.104 \\
\hline & $\begin{array}{c}\text { Equal } \\
\text { variances not } \\
\text { assumed }\end{array}$ & & & -0.087 & 88.725 & 0.931 & -0.009 & 0.104 \\
\hline
\end{tabular}

One-way repeated measures ANOVA analysis is employed for analyzing the oral complexity of the three tests in EC and $\mathrm{CC}$ in order to gauge the changes among these three tests. The results show that the difference among the three tests in $\mathrm{EC}(\mathrm{F}=0.169, \mathrm{P}=0.767)$ and $\mathrm{CC}(\mathrm{F}=0.289, \mathrm{P}=0.626)$ has no statistical significance. In other words, there is no obvious difference among the three tests in EC or CC.

\section{The Effect of Blended Learning on Oral Accuracy}

As is presented in Table 4, the data of Sig. (2-tailed) is 0.251 , which is more than 0.05 , suggesting that there is no obvious difference between EC and CC in terms of the error-free clause/clause ratio. Therefore, the participants' oral accuracy is at the same level, and both classes can be involved in the experiment.

TABLE 4

INDEPENDENT-SAMPLES T TEST OF ACCURACY PRETEST FOR EC AND CC

\begin{tabular}{|c|c|c|c|c|c|c|c|c|}
\hline \multirow{4}{*}{ Pre-test } & & \multicolumn{2}{|c|}{$\begin{array}{l}\text { Levene's Test } \\
\text { for Equality } \\
\text { of Variances }\end{array}$} & \multicolumn{5}{|c|}{ T-test for Equality of Mean } \\
\hline & & $\mathrm{F}$ & Sig & $\mathrm{t}$ & $\mathrm{df}$ & Sig (2-tailed) & $\mathrm{M}$ & Std \\
\hline & $\begin{array}{c}\text { Equal } \\
\text { variances } \\
\text { assumed }\end{array}$ & \multirow{2}{*}{10.68} & \multirow{2}{*}{0.002} & 1.157 & 88 & 0.251 & 0.013 & 0.115 \\
\hline & $\begin{array}{c}\text { Equal } \\
\text { variances not } \\
\text { assumed }\end{array}$ & & & 1.157 & 62.763 & 0.252 & 0.013 & 0.115 \\
\hline
\end{tabular}

According to Table 5, the value of Sig. (2-tailed) is 0.000 , which is lower than 0.05 . In addition, the mean error-free clause/clause ratio for EC (0.603) is noticeably higher than that of CC (0.335). Therefore, it is safe to reach the conclusion that EC differs significantly from CC in terms of accuracy gains evidenced by immediate test results, and the blended learning method can effectively improve the participants' oral accuracy in EC in the short term. 
TABLE 5

INDEPENDENT SAMPLES TEST OF ACCURACY IMMEDIATE POST-TEST FOR EC AND CC

\begin{tabular}{|c|c|c|c|c|c|c|c|c|}
\hline \multirow{4}{*}{$\begin{array}{l}\text { mmediate } \\
\text { post-test }\end{array}$} & 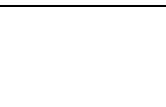 & \multicolumn{2}{|c|}{$\begin{array}{c}\text { Levene's Test } \\
\text { for Equality } \\
\text { of Variances }\end{array}$} & \multicolumn{5}{|c|}{ T-test for Equality of Mean } \\
\hline & & $F$ & Sig & $\mathrm{t}$ & df & $\begin{array}{c}\text { Sig } \\
\text { (2-tailed) }\end{array}$ & M & Std \\
\hline & $\begin{array}{c}\text { Equal } \\
\text { variances } \\
\text { assumed }\end{array}$ & \multirow{2}{*}{9.649} & \multirow{2}{*}{0.003} & 16.100 & 88 & 0.000 & 0.201 & 0.012 \\
\hline & $\begin{array}{c}\text { Equal } \\
\text { variances not } \\
\text { assumed }\end{array}$ & & & 16.100 & 59.545 & 0.000 & 0.201 & 0.012 \\
\hline
\end{tabular}

Table 6 indicates that in the delayed post-test, the value of Sig.(2-tailed) is 0.012, which is also less than 0.05 . In addition, the mean accuracy score of EC (0.597) was remarkably higher than that of $\mathrm{CC}(\mathrm{M}=0.351)$ in the delayed test. Therefore, the conclusion can be drawn that the difference between EC and CC in the delayed test is obvious, and the blended learning method has long-term effect on the development of the participants' oral accuracy in EC.

One-way repeated measures ANOVA analysis shows that there exists observable difference among the three tests in $\mathrm{EC}(\mathrm{F}=18.014, \mathrm{P}=0.000)$, while there is no obvious difference among the three tests in $\mathrm{CC}(\mathrm{F}=0.676, \mathrm{P}=0.015)$. In other words, there are some remarkable changes throughout the test performance of EC but not CC. As a result, it is clear that compared with the traditional teaching method, the application of blended learning method can significantly and consistently increase junior middle school students' oral accuracy.

TABLE 6

INDEPENDENT SAMPLES TEST OF ACCURACY DELAYED POST-TEST FOR EC AND CC

\begin{tabular}{|c|c|c|c|c|c|c|c|c|}
\hline \multirow[t]{2}{*}{ Period } & & \multicolumn{2}{|c|}{$\begin{array}{l}\text { Levene's Test } \\
\text { for Equality } \\
\text { of Variances }\end{array}$} & \multicolumn{5}{|c|}{ T-test for Equality of Mean } \\
\hline & & $\mathrm{F}$ & Sig & $\mathrm{t}$ & df & $\begin{array}{c}\text { Sig } \\
\text { (2-tailed) }\end{array}$ & M & Std \\
\hline \multirow{2}{*}{$\begin{array}{l}\text { Delayed } \\
\text { post-test }\end{array}$} & $\begin{array}{c}\text { Equal } \\
\text { variances } \\
\text { assumed }\end{array}$ & \multirow{2}{*}{6.590} & \multirow{2}{*}{0.012} & 9.438 & 89 & 0.000 & 0.246 & 0.026 \\
\hline & $\begin{array}{c}\text { Equal } \\
\text { variances not } \\
\text { assumed }\end{array}$ & & & 9.462 & 85.368 & 0.000 & 0.246 & 0.026 \\
\hline
\end{tabular}

\section{The Effect of Blended Learning on Oral Fluency}

As is shown in Table 7, the data of Sig. (2-tailed) is 0.673 , which is more than 0.05 , suggest that there is no significant difference between EC and CC in terms of Rate B scores. Therefore, the participants' oral fluency is at the same level, and both classes can be involved in the experiment.

TABLE 7

INDEPENDENT-SAMPLES T TEST OF FLUENCY PRETEST FOR EC AND CC

\begin{tabular}{|c|c|c|c|c|c|c|c|c|}
\hline \multirow{4}{*}{ Pre-test } & & \multicolumn{2}{|c|}{$\begin{array}{c}\text { Levene's Test } \\
\text { for Equality } \\
\text { of Variances }\end{array}$} & \multicolumn{5}{|c|}{ T-test for Equality of Mean } \\
\hline & & $\mathrm{F}$ & Sig & $\mathrm{t}$ & $\mathrm{df}$ & Sig (2-tailed) & $\mathrm{M}$ & Std \\
\hline & $\begin{array}{c}\text { Equal } \\
\text { variances } \\
\text { assumed }\end{array}$ & \multirow{2}{*}{3.592} & \multirow{2}{*}{0.061} & 0.423 & 90 & 0.673 & 0.498 & 1.177 \\
\hline & $\begin{array}{c}\text { Equal } \\
\text { variances not } \\
\text { assumed }\end{array}$ & & & 0.420 & 84.795 & 0.676 & 0.498 & 1.185 \\
\hline
\end{tabular}

According to Table 8, the value of Sig.(2-tailed) is 0.008 , which is less than 0.05 . In addition, the mean Rate B score for EC (60.111) is noticeably higher than that of CC (53.978). Therefore, it is safe to draw the conclusion that EC differs significantly from $\mathrm{CC}$ in terms of fluency gains evidenced by the immediate test results, and the blended learning method can effectively promote the participants' oral fluency in EC in the short term. 
TABLE 8

INDEPENDENT SAMPLES TEST OF FLUENCY IMMEDIATE POST-TEST FOR EC AND CC

\begin{tabular}{|c|c|c|c|c|c|c|c|c|}
\hline Period & & $\begin{array}{l}\text { Leve } \\
\text { for } \\
\text { of } \mathrm{V}\end{array}$ & $\begin{array}{l}\text { Test } \\
\text { ity } \\
\text { ces }\end{array}$ & \multicolumn{5}{|c|}{ T-test for Equality of Mean } \\
\hline \multirow{3}{*}{$\begin{array}{l}\text { Immediate } \\
\text { post-test }\end{array}$} & & $\mathrm{F}$ & Sig & $\mathrm{t}$ & df & $\begin{array}{c}\text { Sig } \\
\text { (2-tailed) }\end{array}$ & M & Std \\
\hline & $\begin{array}{c}\text { Equal } \\
\text { variances } \\
\text { assumed } \\
\end{array}$ & 0.450 & 0.504 & 6.648 & 89 & 0.008 & 6.785 & 2.269 \\
\hline & $\begin{array}{c}\text { Equal } \\
\text { variances not } \\
\text { assumed }\end{array}$ & & & 6.662 & 84.375 & 0.008 & 6.785 & 2.248 \\
\hline
\end{tabular}

Table 9 indicates that in the delayed post-test, the value of Sig. (2-tailed) is 0.000, which is also less than 0.05 . in addition, the mean Rate B score of EC (59.578) was noticeably higher than that of CC (53.674) in the delayed test. Therefore, the conclusion can be made that the difference between EC and CC in the delayed test is conspicuous, and the blended learning method has long-term effect on the development of the participants' oral fluency in EC.

TABLE 9

INDEPENDENT SAMPLES TEST OF FLUENCY DELAYED POST-TEST FOR EC AND CC

\begin{tabular}{|c|c|c|c|c|c|c|c|c|}
\hline \multirow{4}{*}{$\begin{array}{l}\text { Delayed } \\
\text { post-test }\end{array}$} & & \multicolumn{2}{|c|}{$\begin{array}{c}\text { Levene's Test } \\
\text { for Equality } \\
\text { of Variances }\end{array}$} & \multicolumn{5}{|c|}{ T-test for Equality of Mean } \\
\hline & & $\mathrm{F}$ & Sig & $\mathrm{t}$ & df & $\begin{array}{c}\text { Sig } \\
\text { (2-tailed) }\end{array}$ & M & Std \\
\hline & $\begin{array}{c}\text { Equal } \\
\text { variances } \\
\text { assumed }\end{array}$ & \multirow{2}{*}{1.154} & \multirow{2}{*}{0.286} & 5.903 & 89 & 0.000 & 5.903 & 1.000 \\
\hline & $\begin{array}{c}\text { Equal } \\
\text { variances not } \\
\text { assumed }\end{array}$ & & & 5.920 & 84.144 & 0.000 & 5.903 & 0.997 \\
\hline
\end{tabular}

One-way repeated measures ANOVA analysis indicates the existence of marked distinction among the three tests in $\mathrm{EC}(\mathrm{F}=51.868, \mathrm{P}=0.000)$. In contrast, no obvious difference is found among the three tests in $\mathrm{CC}(\mathrm{F}=1.697, \mathrm{P}=0.199)$. In other words, there are some remarkable changes in the test performance of EC but not CC. Overall, it is obvious that compared with the traditional teaching method, the application of blended learning method can noticeably and consistently develop junior middle school students' oral fluency.

\section{Results of the Interview}

Complexity measures do not show the effectiveness of blended learning over traditional teaching, and analysis of the transcripts of the participants' responses to the test items makes it clear that most of them, in both EC and CC, were inclined to use simple vocabulary and sentences rather than complex grammatical structure to generate oral output. In the interview, the participants stated their reasons for avoiding the use of elaborate language in their responses, as one of the participants in EC put it, "I don't think the complexity of my spoken English has been improved. In order to avoid mistakes during the test, I subconsciously chose simple words and sentences, or expressions that I was confident about. I think what matters the most is to express the meaning clearly." Another participant provided additional insight by commenting: "If I use more complex sentences, I need to think for a longer time, and my answers will not sound natural and smooth. This will affect my performance and scores in the test".

Accuracy measures demonstrate the superiority of the blended learning method over the traditional teaching method. Transcript analysis of the participants' responses to the test items supports the effectiveness of blended learning. Particularly, for phonetic accuracy, before the experiment, the participants were unable to distinguish the pronunciation

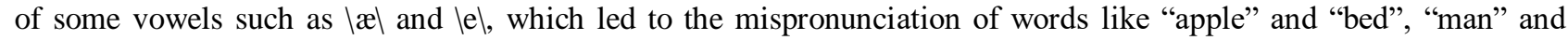
"men". After receiving teacher feedback through the platform, the participants were capable of listening to the correct pronunciation as many times as they wanted to, and compared their pronunciation with the teacher's. For grammatical accuracy, the participants made fewer errors in the plural form of nouns and verb tenses through incorporating corrective feedback from the teacher. During the interview, the usefulness of online teacher feedback was approved by the participants, as one participant mentioned, "Teacher feedback from the platform enables me to know precisely where my problems are without feeling embarrassed. During the test, I became more careful with my speech so that I wouldn't repeat my mistakes".

Fluency measures suggest the beneficial effect of blended learning on the participants' oral production. Further transcript analysis shows that the improvement in fluency is predominantly reflected in the substantially reduced number of pauses and repetitions. According to the interview responses, some participants attributed to the improvement in oral fluency to their increased self-regulation ability, as one of the participants commented, "I have the opportunity to study at my own pace and the freedom to choose what and how to learn. The flexibility reduced my anxiety in learning oral English. This is why I speak more fluently than before." 


\section{B. Discussion}

The results indicate that compared with the traditional teaching method, the application of blended learning to oral English teaching does not have a marked effect on the development of junior middle school students' oral complexity. This may be accounted for by three factors. The first one concerns the participants' limited processing capacity. According to Skehan and Foster (1997), the limited processing capacity that learners possess can create trade-offs between CAF. That is to say, when CAF are in a state of mutual tension, achieving one may be at the expense of one or the other two. Furthermore, they pointed out that in the completion of tasks in which learners do not need to devote much attention to encoding the propositional content, they often choose to attend to accuracy over complexity. In this study, the test items include answering questions, giving oral presentation and impromptu speech according to the prompts. These tasks are of relatively clear inherent structure, and as such the participants were less likely to use their planning time to reflect on how to express their ideas in a more complex way, resulting in the fact that little of their capacity was allocated to a focus on complexity. The second reason relates to the participants' oral proficiency. In the present study, the majority of the participants are at low intermediate level of English proficiency, and in the classroom, most of the time, they engage in drills and other mechanical exercises when practicing oral English. As noted by Housen et. al. (2012), the complexity of learners' language is influenced by the degree to which explicit declarative knowledge, deriving from the acquisition of the relevant linguistic structures and rules, has been proceduralized and become implicit. The participants' low English proficiency, together with their lack of mental resources, including attentional focus and working memory (Skehan, 1998), may contribute to the failure of the conversion from declarative knowledge to procedural knowledge, and eventually detract from the complexity of their oral performance. The final reason may be concerned with the discourse features of the oral responses elicited. As Pallotti (2009) noted, linguistic complexity varies by genre (e.g., small talk vs. argumentative essays) and individual stylistic choices. The study conducted by Olinghouse and Wilson (2012) also showed that compared with the genres of story and informative writings, the genre of persuasive elicited the most complex output from fifth graders. In a similar vein, the genres of small-talk (e.g., questions and answers) and narrative (e.g., oral presentation and impromptu speech) that the test items in this study intended to elicit may to some degree compensate for the effects of blended learning on the participants' oral complexity.

The results also show that compared with the traditional teaching method, the application of blended learning to oral English teaching has noticeable and positive effect on the development of junior middle school students' oral fluency and accuracy. The improvement of oral accuracy and fluency may be accounted for by the increase in the participants' self-regulation. In the current study, regulation occurred at three levels: object-, other-, and self-regulation. For objectregulation, the participants exploited the online platform, including the various interactive features of network-based learning to obtain exposure to input and reflect on their output. For other-regulation, they were able to receive feedback, guidance, and assistance from their peers and the teacher both online and offline to complete the tasks that they were not able to accomplish on their own. For self-regulation, through peer and teacher scaffolding, they traversed the ZPD and became more autonomous learners, being capable of searching for online resources, social media tools, and engagement in classroom activities to enrich their language learning experiences. It is widely accepted that selfregulation is a behavioral process coming after or as a result of regulation by others (DeVries, 2000; Lantolf \& Thorne, 2015). In the current study, on the basis of object- and other-regulation, the participants internalized the assistance they had been provided and reached a higher level of development in their oral accuracy and fluency.

The participants' self-regulation has also been strengthened owing to the blended learning environment. According to Lynch and Dembo (2004), five self-regulatory attributes are likely to be predictive of learners' academic performance in a blended learning context: intrinsic goal orientation, self-efficacy for learning and performance, time and study environment management, help seeking, and Internet self-efficacy. On the whole, the participants in the current study demonstrated these five attributes. Specifically, intrinsic goal orientation is "the degree to which a learner participates in a learning task in order to meet a personal challenge, satisfy personal curiosity, and/or attain personal mastery over the elements of the task" (ibid, p.3). In the current study, the participants were quite curious about the effectiveness of the online platform, and faced many challenges posed by the blended learning environment. This drove them to achieve satisfactory performance in the tasks to find an effective method to improve their oral English. In addition, prior to the study, the participants had ample experience with distance learning during the pandemic and were quite familiar with the operation of the online platform. The fact that they felt confident in and comfortable with the combination of online and offline learning mode undoubtedly contributed to the increase in their self-efficacy for learning and the use of the Internet. Moreover, in the process of blended learning, the participants needed to discuss their online activities such as previewing course content, responding to their classmates' audio recording, completing assignment with their peers and the teacher during on-campus classroom meetings. In other words, in the blended environment, the participants learned autonomously and collaboratively with each other, which is beneficial for their management of time and study environment. The feedback they obtained on their oral performance and the assistance they received in face of technical problems were also the important source for seeking help. Overall, the five regulatory attributes that the participants exhibited in the blended context ensures a smooth transition they underwent from object- and other-regulation to selfregulation. 
An additional explanation of the participants' progress in oral fluency and accuracy can be possibly found in the DCT. The DCT assumes that the visual-verbal mode of presentation is more effective for the reception and production of incoming information. In the current study, the blended learning environment enabled the participants to access text, images, audio and video clips simultaneously. This multi-modal presentation of input lessened their cognitive burden, facilitated the comprehension, recall, recognition, and the reception of the learning materials, and eventually resulted in the more accurate use of linguistic forms and more fluent speech production.

\section{CONCLUSION}

\section{A. Major Finding}

This study investigates the effect of blended learning on the development of junior middle school students' oral competence, including complexity, accuracy and fluency. The results suggest that blended learning does not have an obvious effect on the increase in oral complexity. That is to say, the participants did not choose to use more complex sentence structures such as clauses to express their ideas after learning oral English in a blended environment. Additionally, blended learning has a remarkable immediate and delayed effect on the improvement of oral accuracy. Specifically, the participants were more accurate in their pronunciation and grammar use. Likewise, blended learning has a noticeable effect on the gain in fluency, as the participants were able to articulate more meaningful syllables in both the short and long term. The findings of the study indicates that compared with the traditional teaching methods, in the blended environment, foreign language learners are able to take advantage of the combination of online and offline instruction to move from object- and other-regulation to self-regulation, and make use of the multimodality that blended learning offers to store and internalize the input they have access to.

\section{B. Implications}

The findings of this study have valuable theoretical and practical implications for oral English teaching in junior middles schools. Theoretically, very few studies on blended learning have been conducted in relation to the theories of regulation and the DCT, and this study enriches the existing research by incorporating these two theories as the robust explanatory framework. Additionally, it provides some theoretical references and guidelines for future studies on the effectiveness of blended learning for the development of oral proficiency. Practically, this study throws some light on the instructional model for teaching oral English in a blended context. This model is primarily based on the four-step pedagogical method (Wang, 2014) combined with various types of speaking activities and the use of multimedia learning tools. The findings of this study show that this model was useful for the improvement of oral competence and was positively perceived by the learners.

\section{Limitations and Directions for Future Studies}

Conclusions drawn from the results of this study are limited in several aspects. First, since there are only 92 participants in this study, the sample size is relatively small. Second, this study only lasted 12 weeks, while the development of oral English competence, especially complexity, accuracy and fluency, is a long process. Thirdly, variables that may impact on the improvement of oral competence are not included, for example, affective factors such as anxiety, motivation, willingness to communicate, and others. On this basis, future studies ought to be conducted with a larger population. In addition, longitudinal studies are needed for the investigation of oral competence development over a longer period of time. Moreover, the moderating effect of affective variables such as anxiety should also be taken into consideration. Finally, the theories of regulation and the DCT can be complemented with linguistics theories, for example, the Contrastive Analysis Hypothesis, to provide a more comprehensive and holistic explanation for the effectiveness of blended learning.

\section{ACKNOWLEDGMENTS}

This paper is part of results of the Youth Project sponsored by Hunan Provincial Planning Office of Social Sciences, Hunan Province, China (Grant No. 17YBQ076).

\section{REFERENCES}

[1] Ayesha, A. (2020). Learner autonomy in a blended learning English language course: a case study of a Pakistani university. Doctoral dissertation, University of Glasgow.

[2] Bahanshal, D. A. (2013). The effect of large classes on English teaching and learning in Saudi secondary schools. English Language Teaching, 6(11), 49-59.

[3] Barnum, C., \& Paarmann, W. (2002). Bringing induction to the teacher: A blended learning model. THE Journal, 30(2), 56-60.

[4] Borglum, R. N. (2016). The effects of blended learning on critical thinking in a high school Earth Science class. Master thesis, University of Northern Iowa.

[5] Ceylan, V. K., \& Kesici, A. E. (2017). Effect of blended learning to academic achievement. Journal of Human Sciences, 14(1), 308-320.

[6] Chambers, F. (1997). What do we mean by fluency? System, 25(4), 535-544.

[7] Ellis, R. (2003). Task-based language learning and teaching. Oxford University Press. 
[8] Ellis, R. (2008). The study of second language acquisition (2nd ed.). Oxford University Press.

[9] Ellis, R., \& Barkhuizen, G. (2005). Analysing learner language. Oxford University Press.

[10] Evans, J. C., Yip, H., Chan, K., Armatas, C., \& Tse, A. (2020). Blended learning in higher education: professional development in a Hong Kong university. Higher Education Research \& Development, 39(4), 643-656.

[11] Foster, P., \& Skehan, P. (1996). The influence of planning on performance in task-based learning. Studies in Second Language Acquisition, 18(3), 299-324.

[12] Freed, B. F. (2000). Is fluency, like beauty, in the eyes (and ears) of the beholder? In H. Riggenbach (Ed.), Perspectives on fluency (pp. 243-265). University of Michigan Press.

[13] Gao, Yang. (2019). The Applied Research of Blended Learning Model in English Speaking and Listening Teaching of Primary School. M.A. thesis, Tianjing University.

[14] Garrison, D. R., \& Kanuka, H. (2004). Blended learning: Uncovering its transformative potential in higher education. The internet and higher education, 7(2), 95-105.

[15] Goh, C. C. M. (2007). Teaching speaking in the language classroom. SEAMEO Regional Language Centre.

[16] Gong, Wen. (2008). A study of blended learning theory applied to college spoken English teaching. M.A. thesis, Chongqing University.

[17] Graham, C. R. (2006). Blended learning systems: definition, current trends, and future directions. In C. J. Bonk, \& C. R. Graham (Eds.), The handbook of blended learning: Global perspectives, local designs (pp. 3-21). Pfeiffer Publishing.

[18] Hesse, L. (2017). The effects of blended learning on K-12th-grade students. Graduate Research Papers, 116.

[19] Horn, M. B., \& Staker, H. (2011). The rise of K-12 blended learning. Innosight institute, 5, 1-17.

[20] Housen, A., \& Kuiken, F. (2009). Complexity, accuracy, and fluency in second language acquisition. Applied linguistics, 30(4), 461-473.

[21] Koponen, M., \& Riggenbach, H. (2000). Overview: Varying perspectives on fluency. In H. Riggenbach (Ed.), Perspectives on fluency (pp. 5-24). Michigan: The University of Michigan Press.

[22] Lennon, P. (1990). Investigating fluency in EFL: A quantitative approach. Language learning, 40(3), 387-417.

[23] Liu, Hui. (2020). A teaching research on improving junior high school students' oral English based on Ekwing platform hierarchical assignments. M.A. Thesis. Southwest University.

[24] Lopez-Perez, M. V., Perez-Lopez, M. C., \& Rodriguez-Ariza, L. (2011). Blended learning in higher education: Students' perceptions and their relation to outcomes. Computers \& education, 56(3), 818-826.

[25] Ma, Zhilian. (2018). Effect of oral presentation on students' English speaking ability in junior middle school. M.A. Thesis. Northwest Normal University.

[26] Norris, J. M., \& Ortega, L. (2003). Defining and measuring SLA. In C. J. Doughty \& M. H. Long (Eds.). Handbook of second language acquisition (pp. 717-761). Wiley-Blackwell Publishing.

[27] Ong, J., \& Zhang, L. J. (2010). Effects of task complexity on the fluency and lexical complexity in EFL students' argumentative writing. Journal of second language writing, 19(4), 218-233.

[28] Osgerby, J. (2013). Students' perceptions of the introduction of a blended learning environment: An exploratory case study. Accounting Education, 22(1), 85-99.

[29] Paivio, A. (1991). Dual coding theory: Retrospect and current status. Canadian Journal of Psychology, 45(3), 255.

[30] Saunders, W. M., \& O’Brien. (2006). Oral language. In F. Genesee, K. Lindholm-Leary, W. M. Saunders, \& D. Christian (Eds.), Educating English language learners: A synthesis of research evidence (pp. 14-45). Cambridge University Press.

[31] Senturk, C. (2021). Effects of the blended learning model on preservice teachers' academic achievements and twenty-first century skills. Education and Information Technologies, 26(1), 35-48.

[32] Skehan, P. (1998). A cognitive approach to language learning. Oxford University Press.

[33] Skehan, P. (2003). Task-based instruction. Language Teaching, 36(1), 1-14.

[34] Skehan, P. (2009). Modelling second language performance: Integrating complexity, accuracy, fluency, and lexis. Applied linguistics, 30(4), 510-532.

[35] Vygotsky, L. (1978). Interaction between learning and development. Readings on the Development of Children, 23(3), 34-41.

[36] Wang, Yuxi. (2021). An action research on multidimensional interactive teaching in oral English teaching in a junior middle school. M.A. Thesis. Changchun Normal University.

[37] Wang, Z. (2014). Developing accuracy and fluency in spoken English of Chinese EFL learners. English Language Teaching, $7(2), 110-118$.

[38] Wolfe-Quintero, K., Inagaki, S., \& Kim, H. Y. (1998). Second language development in writing: Measures of fluency, accuracy, \& complexity. University of Hawaii Press.

[39] Zhang, Yanju. (2020). The applied research of mobile terminal APP to oral English teaching of junior middle school -Taking "speak English fluently" as an example. M.A. Thesis. Hebei Normal University Of Science and Technology.

[40] Zou, Yan. (2016). Washback of the English oral test of the senior high school entrance examination on junior high school English classroom teaching and learning: An empirical study. M.A thesis, Hunan Normal University.

Xuan Teng was born in Changsha, Hunan Province, China in 1982. He received his PhD degree in Applied Linguistics and Technology from Department of English, College of Liberal Arts and Sciences, Iowa State University, USA in 2015. Now he is a lecturer at Foreign Studies College of Hunan Normal University. His research interest includes second language acquisition, computer-assisted language learning, and English teaching methodology.

Ying Zeng was born in Jiangxi Province, China in 1996. She is now studying for her M.A degree in English Language Teaching at Foreign Studies College of Hunan Normal University, Hunan Province, China. 